\title{
Relationship between Total Quality Management Practices and Financial Performance of Small and Medium Sized Manufacturing Companies in the Philippines
}

\author{
Shaneil R. Dipasupil ${ }^{*}$ and Robert S. Dipasupil ${ }^{2}$ \\ 'Academy of General Studies, Hanseo University, Chungcheongnam-do, South Korea; \\ s_dipasupil@yahoo.com, \\ 2Department of Business Administration \& Information System, Arba Minch University, \\ Sawla, Gamo Gofa, Ethiopia; r_dipasupil@yahoo.com
}

\begin{abstract}
Objectives: To identify the predominance of Total Quality Management (TQM) practices in small and medium sized manufacturing companies in the Philippines and its relationship to financial performance. Methods: Questionnaires were administered among the owners/managers of the 50 small and medium manufacturing firms which were chosen through multi-stage random sampling. The questionnaire was composed of questions relating to quality practices in terms of management commitment and leadership, continuous improvement, total customer satisfaction, employee involvement, education and training, and reward and recognition. Descriptive statistics and Pearson Product Moment of Correlation were used to analyse the data in the study. Findings: The results reveal that the TQM practices in terms of management leadership and commitment, customer satisfaction, and continuous improvement are highly predominant while employee involvement, training and education, and rewards and recognition are only moderately predominant. Furthermore, aside from continuous improvement which was found to have a significant relationship to the solvency of the companies, there was no significant relationship between the other areas of TQM and the financial performance of the companies in terms of liquidity, solvency and profitability. These results run parallel with the fact that the rewards of TQM are highly long-range which means that any investment in the quality efforts now may not necessarily lead to any positive improvement in financial performance at once, or in the short term. This is the reason why there is a high degree of management commitment necessary in order to keep the improvement efforts afloat. This study has produced an important insight that a long-term dedicated SME quality development campaign can be an ideal strategy to improve productivity. Improvements: A comparison on the adoption of TQM between companies in terms of time period would give insights of the effects of TQM, if any, when conducted over long-term.
\end{abstract}

Keywords: Profitability, Quality, Small and Medium Enterprise, Total Quality Management

\section{Introduction}

The beginning of the 21st century has witnessed a wide spectrum of revolutionary changes in mankind. We have seen technological advancements that were once a product of our wild imagination, but now is part of reality. Economies that used to be self-sufficient are now active players in the global marketplace. Businessmen nowadays have to face the harsh reality of competition. The key issue now is not just how to start a business but how to sustain the business and to ensure its profitability not only in the short-run but in the long-run as well. Since customers are the lifeblood of the business, it is crucial to make certain that their needs are highly met with the products and

${ }^{*}$ Author for correspondence 
services being offered by the firms. Now, more than ever, customers have been very conscious about the quality of goods and services that they receive in order for them to feel that they have the best value for their money. Quality, therefore serves as the measure among customers nowadays whether they will conduct repeat business with the same firm or whether they will buy again the same product in the future.

Since the value of quality is relative, it poses a great challenge for the companies to exceed customer expectations all the time. Moreover, management should also be aware that ensuring the highest standard of quality among its products necessitates a holistic approach. This means that quality should be incorporated not only in the production of output, but in every aspect of management as well.

The main assumption is that quality is equally important for Small and Medium Enterprises and for large corporations. One reason is that some small local companies have been competing simultaneously with foreign firms for a long time. Another reason is that many large firms rely on a number of small companies for parts and services that they use in producing their products. Qualityconscious corporations are demanding higher quality in the goods and services they buy from small businesses; at the same time, they are reducing the number of vendors. The criteria used in deciding which company to keep as a vendor are based almost entirely on cost, quality and revenue. Still another reason is that competition in the global economy has intensified and new challenges have emerged to which small firms have to adapt. Quality and productivity seem to be the core ingredients in a small firm's struggle for survival in these new conditions ${ }^{1}$.

The need for continuous improvement to become part of the organizational culture is highly desired in Small and Medium Enterprises (SMEs) as it is for large companies. Because of the competitive pressures created by globalization, quality became a competitive weapon in most industries. Its role in economic life cannot be discounted. Quality no longer seems to be a competitive advantage, but rather a prerequisite to survival especially for SMEs.

One of the characteristics of a shrinking global market is a kind of competition among firms that is beyond the limits of time and physical distance ${ }^{2}$. Globalization has created an unprecedented rivalry among firms towards market share as well as in access to resources. With internet technology becoming so accessible, distance and time no longer serve as hindrances to scout for products that would best provide the value for the customer's money. With these developments, providing products and services with the highest level of quality has become the new-age norm among firms.

Quality is the ability of the product to satisfy stated and implied requirements ${ }^{3}$. When the expectations of the customers are greater than the actual performance of the product or service, then the product is deemed to have low quality. However, when the actual performance meets or exceeds the expectations of the customers, then the product or service is considered as having a high quality. Today, quality is viewed as a strategy tool used by business firms that aim not only to meet customers' expectations but also to exceed them, in order to attain competitive advantage $\frac{1,3}{3}$. By selling high quality products and services, companies can sell at a higher price through differentiation, thus creating added value to the product ${ }^{4}$.

Total Quality Management is a holistic approach that utilizes systematic quality improvements with the objective of attaining customer satisfaction, enhanced productivity and greater profitability ${ }^{4-7}$. A survey of literature reveals that TQM implementation is a key driver in improving organizational efficiency and long-term profitability through reduction in wastes, shorter lead times, costs savings and greater people involvement $\frac{8-11}{}$. Furthermore, several studies identify that using TQM approach in order to increase the customers' level of satis faction had a significant positive impact on financial performance through minimizing returns and increasing customer loyalty ${ }^{12-14}$. As regards the areas of Total Quality Management, literature shows that quality management models such as Malcolm Baldrige Criteria for Performance Excellence, Deming Application Prize and the ISO Series of Standards among others, recognize that the main components of TQM include customer focus, executive leadership, employee involvement, continuous improvement, human resources education and training and reward and recognition ${ }^{2}$.

Top management provides the direction with which to implement the quality effort of the whole company. The success of these quality efforts depends highly on how committed the top management is ${ }^{4,15}$. In the area of employee involvement, it is assumed that all employees are willing to cooperate and can work effectively in teams in order for the TQM efforts to be successfulı. To fully empower the employees, a vigorous program for education and retraining must be adopted in order to provide them with the right tools and knowledge to adhere to 
internationally accepted standards of quality. Previous studies showed that the success of TQM depend heavily on management commitment and employee empowerment $\mathrm{t}^{15}$.

According to the Small and Medium Enterprises Development Council (SMEDC), in terms of total assets, small enterprises are those having a total asset of $\mathrm{PhP} 3$ to $\mathrm{PhP} 15$ million while medium firms are those having a total asset of PhP15 to PhP100 million exclusive of land. In terms of the number of labor employees, small enterprises have 10 to 99 workers while medium enterprises employ 100 to 199 workers.

As of 2012, 99.6\% of the business enterprises operating in the Philippines are micro, small and medium enterprises. Majority of the Small and Medium Enterprises can be found in the National Capital Region and in Region IV-A (CALABARZON) where Batangas Province is a part of. The SME is a very significant sector in the economy since it employs almost $65.0 \%$ of the total jobs in $2013^{\frac{16}{6}}$.

Current research has established that SMEs have a major role to play in the manufacturing sector in the coming decade. In the past, manufacturing was done in a single location and in an integrated format. But now the trend is to break up the manufacturing process into different modules and these modules are often subcontracted out to the SMEs with the parent company serving as a quality check and as a control of the company's products and services generated. So SMEs have a really significant role to play in the coming decade in manufacturing as well as in the production of services.

The Philippines is still on its way of grappling with the challenges of global quality standards. Recognizing the pivotal role that SMEs play in the economy, it is imperative that this sector keeps abreast with the quality efforts going on worldwide. It is only through quality that a business can stay afloat amidst very stiff competition.

Total Quality Management (TQM) provides a powerful platform on which companies apply quality management not only at the production or service delivery levels, but also on a company-wide scale. Therefore, TQM's potential needs to be exhausted more completely than it ever been. At the same time, the TQM concept will obviously have to be responsive to the dynamic business environment.

The adoption of Total Quality Management in small business setting started with efforts that were associated with employee motivation, needs for resources and gaining competitive advantages ${ }^{17}$. Several researches have been made to highlight the impact of a TQM approach to the overall performance of small and medium enterprises ${ }^{18}$. However, the implementation of TQM among SMEs is not without drawbacks. SME owners view that adopting a holistic approach to quality management entails large cost, requires more staff and the general resistance among employees against any possible changes that may occur. This study aims to provide additional literature that would help business owners to develop their own TQM practices that would enhance their financial performance in the long run.

\section{Objectives of the Study}

This study aims to explore the relationship between Total Quality Management practices among Small and Medium Enterprises and their financial performance in terms of liquidity, solvency and profitability. Specifically, the study aims:

- To identify the predominance of TQM practices in terms of management leadership and commitment; continuous improvement; total customer satisfaction; employee involvement; education and training; and reward and recognition.

- To evaluate the relationship between the areas of TQM and the companies' financial performance in terms of liquidity, solvency and profitability.

\section{Materials and Methods}

The study utilized the descriptive design and involved 50 small and medium sized manufacturing enterprises operating in Batangas Province which were chosen through multi-stage random sampling. Most of the companies that participated in the study are engaged in the production of animal feeds, have been operating for five to ten years now and employ less than 200 workers. The respondents were the chief executive/officer in charge of the sample firms who answered the questionnaires prepared by the researcher. The questionnaire was composed of questions relating to the quality practices in the areas of management commitment and leadership, continuous improvement, total customer satisfaction, employee involvement, education and training and reward and recognition. Furthermore, the financial performance of the companies in terms of solvency, liquidity and profitability 
was explored. Aside from the questionnaire, the researchers also conducted interviews to gather more insights from the respondents. Descriptive statistics was used as well as Pearson Product Moment of Correlation to interpret the gathered data.

\section{Results and Discussion}

\subsection{Predominance of Total Quality Management Practices}

The descriptive analysis revealed that TQM practices in terms of management leadership and commitment, customer satisfaction and continuous improvement are highly predominant among the subject companies while strategies involving employee involvement, training and education and rewards and recognition are moderately predominant among the participating SMEs as shown in Table 1.

TQM connotes an organization-wide approach and the results showed that a very high predominance of TQM practices was not achieved by the companies surveyed. It can be implied that the Small and Medium Enterprises have not yet taken full gear in implementing TQM.

The TQM components that are highly predominant among the surveyed companies include management leadership and commitment, continuous improvement and total customer satisfaction. The high predominance of practicing management leadership and commitment indicates that the companies have full understanding of the importance of getting the support of the top management before any quality effort is being made. Only a strong commitment towards the implementation of TQM standards can guarantee its completion and continuous improvement.

Moreover, a high verbal interpretation in the area of continuous improvement is another positive finding. This suggests that SMEs are fully aware of changes that occur not only in terms of customer preferences but also in terms of business environments, and that the cornerstone of survival is continuous improvement.

Total customer satisfaction is the last component of the Total Quality Management which is found to be highly predominant among the subject companies. Most customers no longer tolerate average quality. Companies today have no choice but to adhere to the highest level of quality if they want to stay in the race. Thus, the task of satisfying customer needs remains a company's top priority.

In contrast, the TQM components that are moderately predominant among the companies consist of employee involvement, education and training, and rewards and recognition. Small and Medium Enterprises are still on their way of making these areas part of their priority plans.

Table 1. Predominance of Total Quality Management practices

\begin{tabular}{|l|l|l|l|}
\hline TQM Components & WM & SD & VI \\
\hline $\begin{array}{l}\text { Management Leadership and } \\
\text { Commitment }\end{array}$ & 4.28 & 0.54 & High \\
\hline Continuous Improvement & 4.09 & 0.61 & High \\
\hline Total Customer Satisfaction & 4.12 & 0.64 & High \\
\hline Employee Involvement & 3.29 & 1.01 & Moderate \\
\hline Training and Education & 3.01 & 1.05 & Moderate \\
\hline Rewards and Recognition & 3.19 & 0.78 & Moderate \\
\hline Overall Weighted Mean & 3.66 & 0.77 & High \\
\hline
\end{tabular}

\subsection{Relationship between Financial Performance and Predominance of TQM Practices}

In terms of the relationship between the financial performance and the predominance of TQM practices, it was found that there is no significant relationship between these two sets of variables as shown in Table 2 . This implies that TQM cannot be readily equated with improved financial performance most especially among the small and medium enterprises.

Among the TQM practices, only continuous improvement significantly correlates with the financial performance of the companies particularly in terms of solvency. All of the other areas of TQM do not relate significantly to the financial performance of the companies. Although the proponents of TQM argue that it can be successfully applied to organizations of all sizes, the results of this study found no evidence to support the assertion that the adoption of TQM practices is of financial benefit to the manufacturing SMEs in the province.

There can be several reasons to explain this. For one, the effect of macroeconomic variables such as economic, political, socio-cultural, technological and educational developments have a great impact on how the operations 
of SMEs are managed $\frac{18}{18}$. The problems that SMEs face in terms of limited access to financing, limited market, low level of technology and lack of economies of scale, all contribute to the inability of the manufacturing SMEs to develop their maximum production capacity and therefore acquire financial leverage that will support any quality improvement efforts by the organization.

In addition, the results of the study run parallel with the fact that the rewards of TQM are highly long-range which means that any investment in the quality efforts now may not necessarily lead to any positive improvement in financial performance at once or in the short term. This is the reason why there is a high degree of management commitment necessary in order to keep the improvement efforts afloat. Moreover, any quality improvement will only lead to tangible financial results if the effort is coupled with the expansion of capacity to produce, thus increasing its production possibility frontier.

Furthermore, this study has produced an important insight that a long-term dedicated SME quality development campaign can be an ideal strategy to improve productivity. As previously pointed out, positive results of
TQM do not appear immediately. So a firm, whether large or small, needs to consider TQM with a long term perspective, requiring a strategic thinking and planning from top management. A strategic plan will identify the major tasks needed to achieve the required changes in the organizational culture and the way of doing business. The plan should establish goals and methods for the implementation of TQM, and should be updated as the conditions within and outside the company change.

The findings of the study run parallel with another study which showed that there is no evidence to suggest that adopting TQM practices improves the financial performance of SMEs ${ }^{19}$. Similarly, the findings of this study are analogous to another study which reported that the quality program among 42 French SMEs had improved organizational performance such as commitment and process quality, but had not significantly improved financial performance ${ }^{20}$. It is possible that the findings could be due to a lack of true commitment by many SMEs to TQM because they implemented TQM not as part of a strategy to improve quality or reduce costs but in response to external pressures.

Table 2. Relationship between financial performance and the predominance of Total Quality Management practices

\begin{tabular}{|l|l|l|l|}
\hline TQM Component & Liquidity & Solvency & Profitability \\
\hline Management Leadership and Commitment & Not significant & Not significant & Not significant \\
\hline Continuous Improvement & Not significant & Significant & Not significant \\
\hline Total Customer Satisfaction & Not significant & Not significant & Not significant \\
\hline Employee Involvement & Not significant & Not significant & Not significant \\
\hline Training and Education & Not significant & Not significant & Not significant \\
\hline Rewards and Recognition & Not significant & Not significant & Not significant \\
\hline
\end{tabular}

\section{Conclusion}

In this paper, it is claimed that TQM practices in terms of management leadership and commitment, customer satisfaction and continuous improvement are highly predominant among the manufacturing SMEs while strategies involving employee involvement, training and education and rewards and recognition are moderately predominant among the participating SMEs. Moreover, this study proved that there is no significant relationship between the financial performance of the manufacturing SMEs and the predominance of TQM practices. However, since TQM is viewed as a holistic approach where the results are long-range, it is still highly suggested that small and medium companies continue to adopt the TQM practices to maintain competitiveness.

\section{References}

1. Gooldberg DA, Cole MS. Effective Total Quality Management practice in an organization. Textbook 2 nd ed. Publication Limited. 2004.

2. Fening F. Impact of quality management practices on the performance and growth of small and medium sized enterprises in Ghana. International Journal of Business and Social Science. 2012; 3(13):1-13.

3. Karapetrovic S, Willborn W. Creating zero-defect students. The TQM Magazine. 1997; 9(4):287-91. Crossref. 
4. Gharakhani D, Hossein R, Mohammad R, Farahmandian A. Total Quality Management and organizational performance. American Journal of Industrial Engineering. 2013; 1(3):46-50.

5. Agus A, Krishman S, Kadir S. The structural impact of TQM on financial performance relative to competitors through customer satisfaction: A study of Malaysian companies. Total Quality Management. 2000; 11(4-6):808-19. Crossref.

6. Douglas T, Judge W. Total Quality Management implementation and competitive advantage: The role of structural control and exploration. Academy Management Journal. 2001; 44(1):158-69. Crossref.

7. Talavera G. TQM adoption and firm performance in the Philippines. Philippine Management Review. 2005; 12:23-44.

8. Harmon RL, Peterson LD. Reinventing the factory: Productivity breakthroughs in manufacturing today. New York: The Free Press; 1990.

9. Flynn BB, Schroeder RG, Sakakibara S. Determinants of quality performance in high and low quality plants. Quality Management Journal. 1995; 4(1):8-25. Crossref.

10. Daniel S, Reitsperger W. Linking quality strategy with management control systems: Empirical evidence from Japanese industry. Accounting, Organizations and Society. 1991; 17:601-18. Crossref.

11. Lee CY. Perception and development of Total Quality Management in small manufacturers: An exploratory study in China. Journal of Small Business Management. 2004; 42(1):102-15.
12. Anderson EW, Fornell C, Lehmann RT. Customer satisfaction, market share and profitability. Journal of Marketing. 1994; 58:53-66. Crossref.

13. Terzioski M, Samson D. The effect of company size on the relationship between TQM strategy and organizational performance. TQM Magazine. 2000; 12(2):144-8. Crossref.

14. Ittner CD, Larcker DF. Measuring the impact of quality initiatives on firm financial performance. Advances in Management of Organization Quality. 1996; 1:1-37.

15. Powell T. Total Quality Management as a competitive advantage: A review and empirical study. Strategic Management Journal. 1995; 16:15-37. Crossref.

16. Ministry of Micro, Small and Medium Enterprises Statistics. 2016. www.dti.gov.ph/dti/index.php/resources/ sme-resources/sme-statistics

17. Nwankwo S. Quality assurance in small business organizations: Myths and realities. International Journal of Quality and Reliability Management. 2000; 7(1):82-99. Crossref.

18. Kusumah L. The essential factors of TQM principles implementation in small industries in Indonesia. Journal of US-China Public Administration. 2013; 10(12): 1190-8.

19. Kober R, Subraamannian T, Watson J. The impact of TQM adoption on small and medium enterprises' financial performance. Accounting and Finance. 2012; 52(2):421-38. Crossref.

20. Ghobadian A, Gallear D. TQM and organization size. International Journal of Operations and Production Management. 1997; 17(2):121-63. Crossref. 